\title{
Sistem Informasi Pendaftaran Santri Baru Dipondok Pesantren Modern Darunn'aim Berbasis Website
}

\author{
Waeisul Bismi ${ }^{1}$, Ade Setiawan ${ }^{2}$, Arina Selawati ${ }^{3}$, Rachmawati Darma Astuti ${ }^{4}$, Tommi Alfian \\ Armawan Sandi ${ }^{5}$ \\ 12345Universitas Bina Sarana Informatika \\ 1'waeisul.wbn@bsi.ac.id, 2ade.dtx@bsi.ac.id, ${ }^{3} a r i n a . a s q @ b s i . a c . i d,{ }^{4}$ rachmawati.rcd@bsi.ac.id, \\ 5tommi.taf@bsi.ac.id
}

\begin{abstract}
Registration information system is one form of technology whose development plays an important role in recruiting new members in a particular agency. In the tradition the boarding school registration system used still uses the system manually in accepting new santri or managing new santri data. The design of the new santri registration information system at this modern website-based boarding school Darunna'im aims to make it easier for new santri candidates to register for the pesantren boarding school online or as a media that facilitates the administration in managing the data of new santri candidates and the features of this website new online. This website is implemented on technology including, using the PHP language as a programming language and MySQL as a database with the design using CSS and using the waterfall method as the flow of making this website. This website is useful for new santri candidates and the administration of Islamic boarding schools in registering as to register prospective santri and managing the data of new santri online with it as an alternative form of media in this modern era, without having directly to the cottage and facilitate data collection.
\end{abstract}

\section{Keywords: Registration, Website, Waterfall, Santri}

\begin{abstract}
Abstrak: Sistem informasi pendaftaran merupakan salah satu bentuk teknologi yang perkembangannya berperan penting dalam merekrut anggota baru pada suatu instansi tertentu. Dalam tradisi pondok pesantren sistem pendaftaran yang digunakan masih menggunakan sistem secara manual dalam menerima santri baru ataupun memanajemen data santri baru. Perancangan Sistem informasi pendaftaran santri baru pada pondok pesantren modern darunnaim berbasis website ini bertujuan untuk mempermudah calon santri baru melakukan pendaftaran kepihak pondok pesanteren secara online atau sebagai media yang memudahkan administrasi dalam memanajemen data calon santri baru dan adapun fitur didalam website ini yakni penyeleksian ujian calon santri baru secara online. Website ini memanfaatkan penggunaan bahasa pemprograman PHP sebagai bahasa pemrograman serta MySQL sebagai database dengan desain menggunakan CSS dan menggunakan metode waterfall sebagai alur pembuatan website ini. Website ini berguna untuk calon santri baru dan pihak administrasi pondok pesantren dalam mendaftarkan diri sebagai calon santri dan memanajemen data calon santri baru dengan secara online sebagai bentuk media alternatif dalam era modern ini, tanpa harus mendaftarkan langsung ke pondok serta memudahkan dalam pendataan.
\end{abstract}

Kata kunci: Pendaftaran, Website, Waterfall, Santri by author and IJSE-Indonesian Journal on Software Engineering.

\section{PENDAHULUAN}

Perkembangan sistem informasi saat ini semakin pesat, berbicara tentang sistem dan informasi, komputer merupakan salah satu bentuk teknologi yang perkembangannya dalam hitungan hari saja dan merupakan suatu media elektronik yang memiliki peran sangat penting 
dalam perkembangan teknologi saat ini diantaranya yakni sistem informasi pendaftaran pada suatu institusi.

Menurut Kusmiati (2017:29) menerangkan bahwa "Media informasi sangat penting adanya untuk mempermudah dalam penyampaian dan penyebaran informasi mengenai kegiatan, fasilitas, dan informasi lainya mengenai sekolah baik Sekolah Menengah Pertama (SMP) maupun Sekolah Menengah Atas (SMA)".

Selama ini proses pendaftaran santri baru masih dilakukan dengan cara yang manual dimana para calon santri diminta untuk melakukan pengisian formulir menggunakan lembaran yang disediakan oleh panitia, dan karena pengisian formulir yang manual ditulis tangan sering menyebabkan kesulitan panitia dalam membaca tulisan tersebut. Selain pengisian formulir yang masih manual juga saat memproses data juga menghabisakan waktu cukup lama, hal ini dapat menyebabkan lambatnya informasi pengumuman bagi peserta. Dengan sistem manual yang dilakukan saat calon santri melakukan pendaftaran maka kemungkinan masih banyak kekurangan data dan terjadinya kesalahan dalam hasil seleksi. Serta pengumuman hasil penerimaan yang diinformasikan masih melalui papan informasi pesantren, sehingga menyulitkan panitia pendaftaran santri baru membutuhkan waktu yang lama dalam menyusun laporan penerimaan santri.

Maka dari itu, implementasi penggunaan website dapat dimanfaatkan oleh admin maupun calon peserta pendaftar untuk memudahkan proses pendaftaran menjadi lebih efisen dan efektif, salah satunya mengurangi penggunaan kertas dan dapat memberi kemudahan admin dalam mengelola data penerimaan santri baru serta memudahkan dalam pendaftaran bagi santri baru, dan tentu dapat memudahkan informasi penerimaan santri baru dengan lebih cepat. Menurut Hidayat dalam Kusmiati (2017:3) menjelaskan yaitu "website merupakan halamanhalaman yang digunakan untuk menampilkan informasi teks, gambar diam atau gerak, animasi, suara, dan bisa juga kombisnasi dari semuanya, dapat memiliki sifat statis maupun dinamis dan membentuk satu rangkaian bangunan yang berkaitan satu dengan yang lain, yang masingmasing terhubung dalam masing-masing jaringan halaman". Berdasarkan latar belakang yang diurai sebelumnya , maka penulis mengangkatnya menjadi sebuah judul skripsi yakni "Rancang bangun sistem informasi pendaftaran santri baru pada pondok pesantren darunna'im berbasis website".

\section{A. TINJAUAN PUSTAKA}

1. Sistem

Menurut Maisyaroh, Ramanda, Komarudin, dan Salim (2014:11) menjelaskan bahwa "Sistem dalam bahasa Latin (systēma) dan bahasa Yunani (sustēma) memiliki arti sebuah kesatuan yang memiliki komponen maupun elemen yang saling terhubung untuk memudahkan aliran informasi, materi atau energi". Sedangkan menurut Prayoga dalam Maulidya (2018:22) menjelaskan "Sistem Informasi merupakan sebuah sistem di dalam satu organisasi sebagai tempat bertemunya kebutuhan pengelohan transaksi harian yang dapat menunjang fungsi dari suatu organisasi operasi bersifat manajerial dengan tujuan dari suatu organisasi untuk dapat diberikan kepada pihak luar tertentu dengan adanya laporan laporan yang dibutuhkan".

2. Informasi

Menurut Darmawan dan Fauzi dalam Maulidya (2018:22) "Informasi merupakan hasil dari pengolahan data, yang tidak semua data dapat menjadi informasi, karena tidak membawa manfaat bagi orang atau golongan tertentu".

3. Sistem Informasi

Menurut Aprilyani dan Syarifuddin (2016:47) "Sistem adalah sebuah tatanan (keterpaduan) yang terdiri atas sejumlah komponen fungsional (dengan satu fungsi dan tugas khusus) yang saling berhubungan dan secara bersama - sama bertujuan untuk memenuhi suatu proses tertentu". Menurut Sutabri dalam Aprilyani dan Syarifuddin (2016:48), "Informasi adalah data yang telah diklasifikasikan, diolah, atau diinterpretasikan untuk digunakan dalam proses pengambilan keputusan. Sistem pengolahan informasi dapat 
memgelola data hingga menjadi sebuah infoemasi yang tadinya tidak berguna menjadi berguna bagi sesorang yang menerima dan membuthkan infoemasinya".

\section{Pemrograman Website}

Menurut Sukanto dalam Mulyani dan Hasanudin (2018:47) menyatakan bahwa "Pemrograman terstruktur adalah konsep atau paradigma atau sudut pandang pemrograman yang membagi-bagi program berdasarkan fungsi-fungsi atau prosedur - prosedur yang dibutuhkan program komputer" serta Menurut Puspitosari dalam [Rizaniar and Sardiarinto, 2015] mengemukakan bahwa, "Website adalah seluruh infomasi yang dapat diakses melalui internet dari seluruh belahan dunia, dengan syarat tetap terkoneksi dengan akses intenet".

\section{Entity Relationship Diagram (ERD)}

Menurut Rosa dan Shalahuddin dalam Maisyaroh (2014:12) menyatakan "Entity Relation Diagram adalah bentuk paling awal untuk membuat suatu perancangan basis data relasional. Sedangkan penggunaan OODBMS dalam perancangan ERD tidak lagi perlu dilakukan.". Dan juga Rosa dan Shalahuddin dalam Maisyaroh (2014:12) menyatakan bahwa "Entity Relation Diagram memiliki aliran notasi diantanya notasi Chen, Barker, notasi Crow's Foot dan notasi lainnya".

\section{Unified Modelling Language (UML)}

Menurut Fowler dalam Sidik dan Rahmawati (2018:121) Unified Modelling Language (UML) adalah "keluarga notasi grafis yang didukung oleh meta-model tunggal, yang membantu pendeskripsian dan desain sistem perangkat lunak, khususnya sistem yang dibangun menggunakan pemrograman berorientasi objek(OO)".

\section{Logical Record Structure (LRS)}

Menurut Kusrini dalam Nugraha (2014:300) "LRS (Logical Record Structure) merupakan representasi dari struktur record record pada tabel-tabel yang terbentuk dari hasil relasi antar himpunan entitas pada diagram E-R". Sedangkan menurut Tabrani dalam (Kuryanti 2016:87) "Logical Record Structure (LRS) dibentuk dengan nomor dari tipe record".

\section{B. METODE PENELITIAN}

Menurut (Rosa \& Shalahuddin, 2013), "Model SDLC air terjun (waterfall) sering juga disebut model sekuensial linier (sequential linier) atau alur hidup (classic life cycle). Model air terjun menyediakan pendekatan alur hidup perangkat lunak secara sekuensial atau terurut dimulai dari analisis, desain, pengkodean, pengujian, dan tahap pendukung (support)". Berikut merupakan tahap-tahapan model waterfall :

1. Analisa kebutuhan perangkat lunak

Proses pengumpulan kebutuhan dilakukan secara intensif untuk mespesifikasi kebutuhan perangkat lunak agar dapat dipahami perangkat lunak seperti apa yang dibutuhkan oleh user. Spesifikasi kebutuhan perangkat lunak pada tahap ini perlu didokumentasikan.

2. Desain

Proses multi langkah yang fokus pada desain pembuatan program perangkat lunak teramasuk struktur data, arsitektur perangkat lunak, representasi antarmuka, dan prosedur pengkodean. Tahap ini mentransilasi apa saja yang dibutuhkan pada suatau perangkat lunak mulai dari analisa kebutuahannya, representasi desai dingga dapat diwujudkan menjadi sebuah program di tahap berikutnya, dan desain dari perangkat lunak yang telah dihasilkan di tahap ini tetap diperlukan proses pendokumentasian..

3. Pembuatan kode program

Desain harus ditranslasikan ke dalam program perangkat lunak. Hasil tahap ini adalah program komputer sesuai dengan desain yang telah dibuat pada tahap desain.

4. Pengujian

Pengujian fokus pada perangkat lunak secara segi lojik dan fungsional dan memastikan bahwa semua bagian sudah diuji. Hal ini dilakukan untuk meminimalisir kesalahan (error) dan memastikan keluaran yang dihasilkan sesuai dengan yang diinginkan. 
5. Pendukung (support) atau Pemeliharaan (maintenance)

Tidak menutup kemungkinan dalam suatau perangkat lunak dapat mengalami suatu perubahan saat sudah diterima atau digunakan oleh user. Perubahan biasanya karena ditemukannya kesalahan yang muncul dan tidak terdeteksi saat pengujian atau perangkat lunak dikembangkan agar dapat beradaptasi dengan kondisi terbaru. Dan dengan tahap pemeliharaan dapat mengulangi proses pengembangan mulai dari analisis spesifikasi untuk perubahan perangkat lunak yang sudah ada, tapi tidak yang tidak menutup kemungkinan adanya perangkat lunak baru.

\section{HASIL DAN PEMBAHASAN}

1. Analisa Kebutuhan

Mengidentifikasi kebutuhan yang diperoleh berdasarkan kebutuhan dan kebutuhan sistem. Pada aplikasi ini kebutuhan pengguna terbagi menjadi 2 kategori pengguna, yaitu:

a. Administrator

1) Administrator dapat mengelola konten website seperti menambah (Create), melihat (read), mengubah (Update) dan menghapuss (Delete) data master yang ada di dalam konten website, seperti: Identitas Website, Cara Pendaftaran, Informasi PSB, email pengguna, jurusan kompetensi dan Mata Pelajaran.

2) Administrator dapat melihat Data Penerimaan Santri Baru, Nilai Raport Siswa dan dokumen-dokumen terkait.

3) Administrator dapat memberikan akses Ujian Saringan Masuk, mengubah Kuis dan memberikan nilai ujian.

b. User (Calon santri Baru)

1) Calon Santri dapat mendaftarkan diri, mengisi biodata dan juga mengikuti ujian saringan masuk.

2) Calon Santri dapat mengunggah dokumen yang diperlukan.

3) Calon Santri dapat menginput Nilai Raport Mata Pelajaran.

4) Calon Santri dapat melihat biaya Pembayaran.

\section{Usecase Diagram}

a. Usecase Diagram Admin

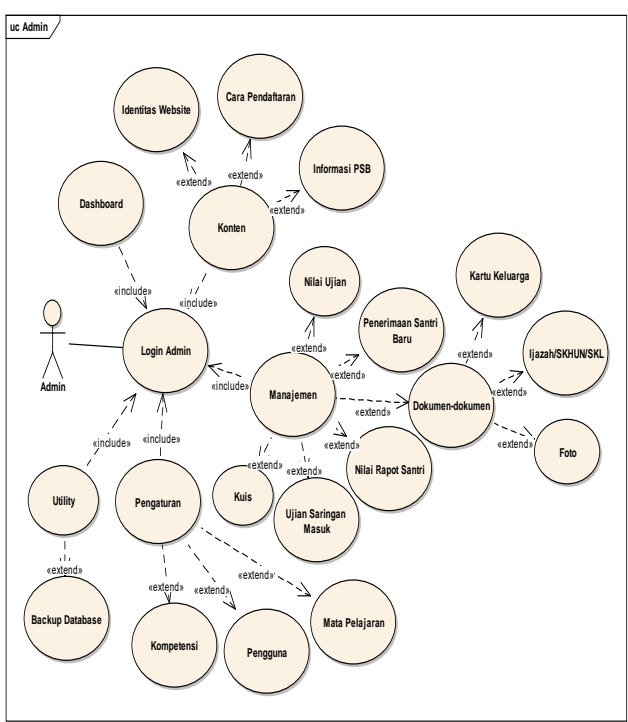

Gambar 1. Usecase Diagram Admin b. Usecase Diagram user

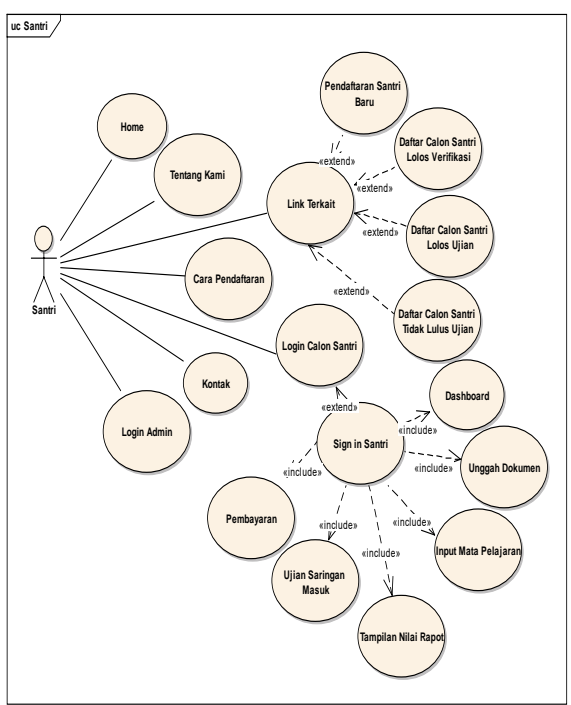

Gambar 2. Usecase Diagram user 
3. Activity Diagram

a. Activity Diagram Admin

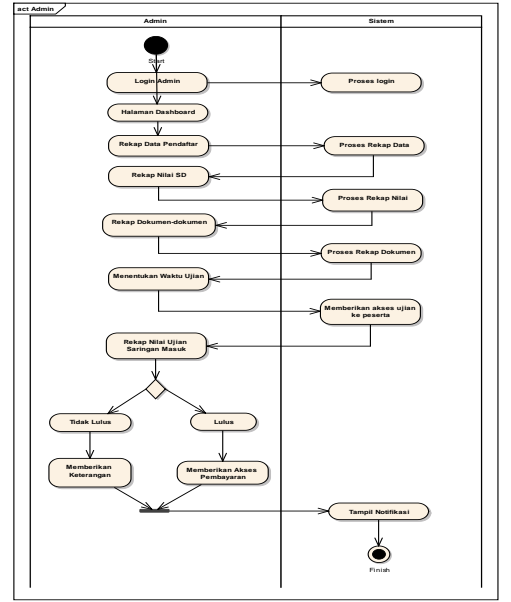

Gambar 3. Activity Diagram Admin

c. Activity Diagram User

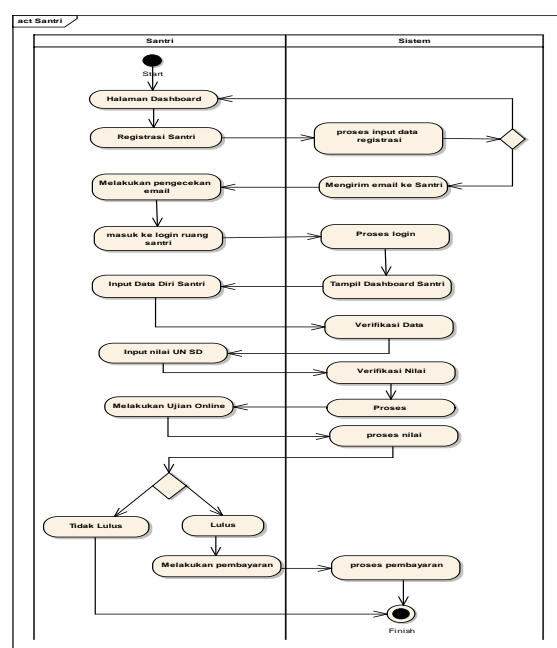

Gambar 5. Activity Diagram User b. Activity Diagram Login Admin

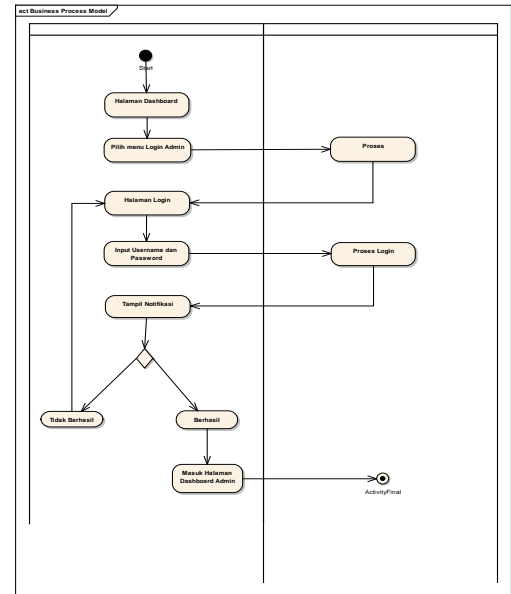

Gambar 4, Activity Diagram login admin

d. Activity Diagram login user

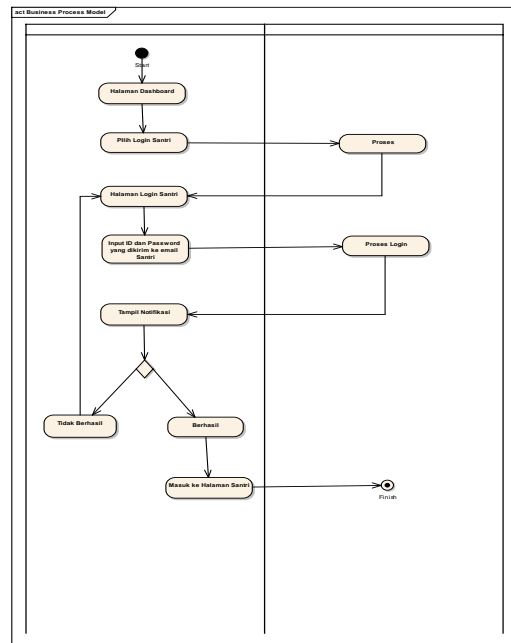

Gambar 5. Activity diagram login user

\section{Component Diagram}

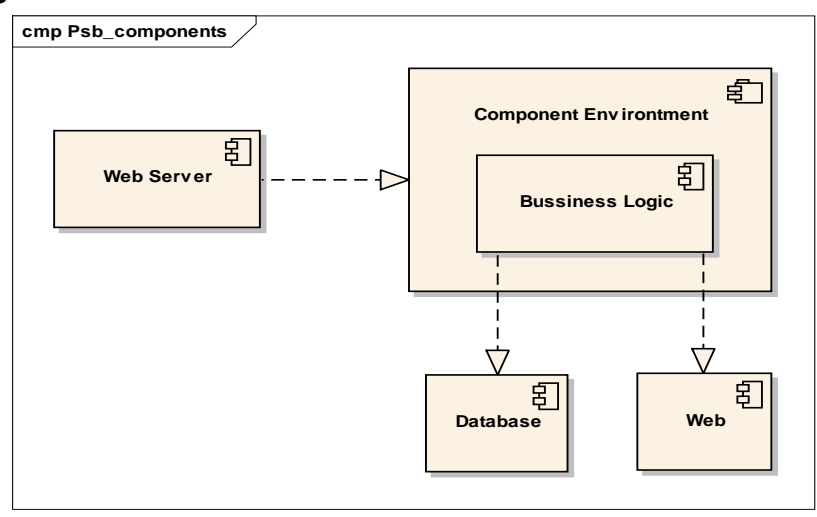

Gambar 6. Component Diagram 
IJSE - Indonesian Journal on Software Engineering, Vol.6, No.2, Desember 2020, 163-171

\section{Deployment Diagram}

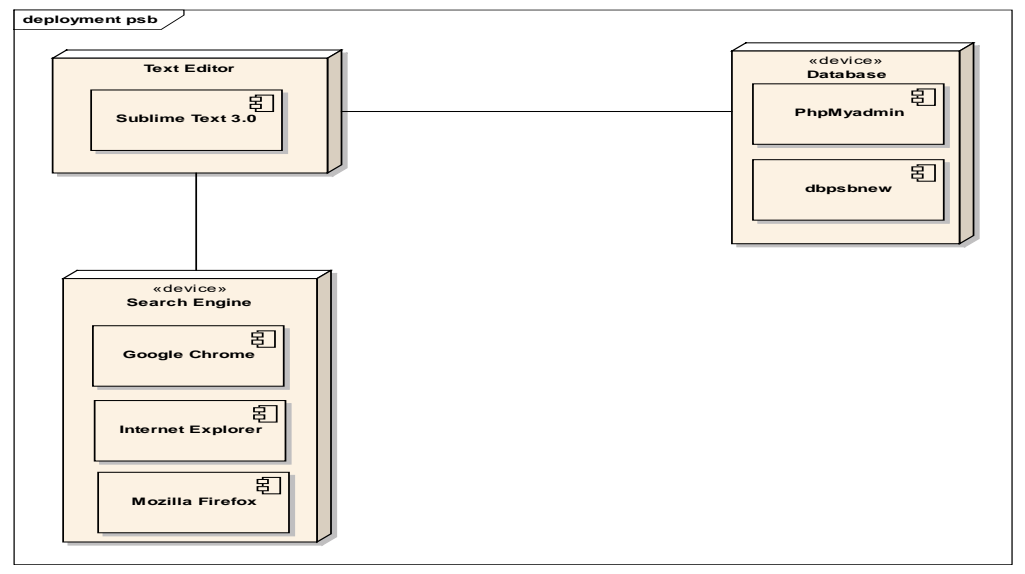

Gambar 7. Deployment Diagram

\section{Database}

a) Entity Relationship Diagram (ERD)

b) Logical Record Structure (LRS)

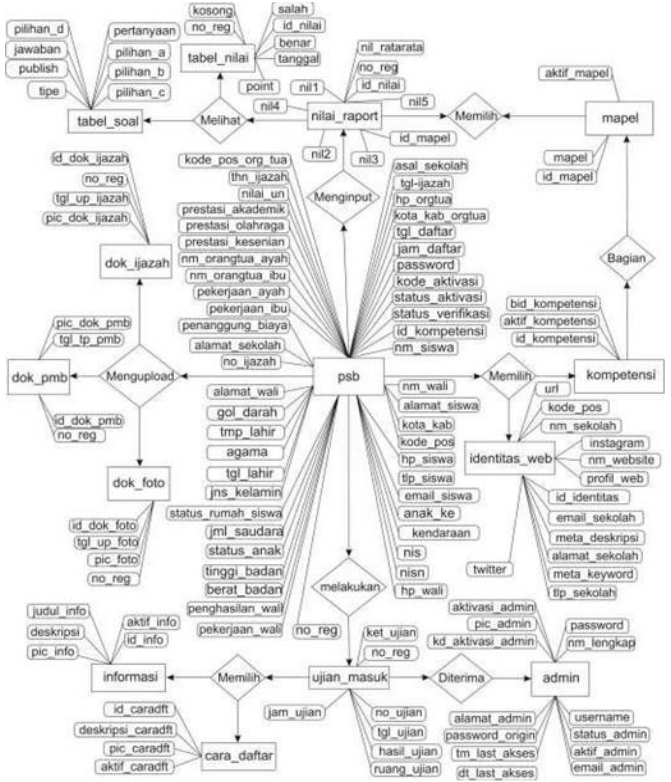

Gambar 8. Entity Relationship Diagram

\section{Implementasi dan Pengujian}

a) Tampilan Halaman Login Admin

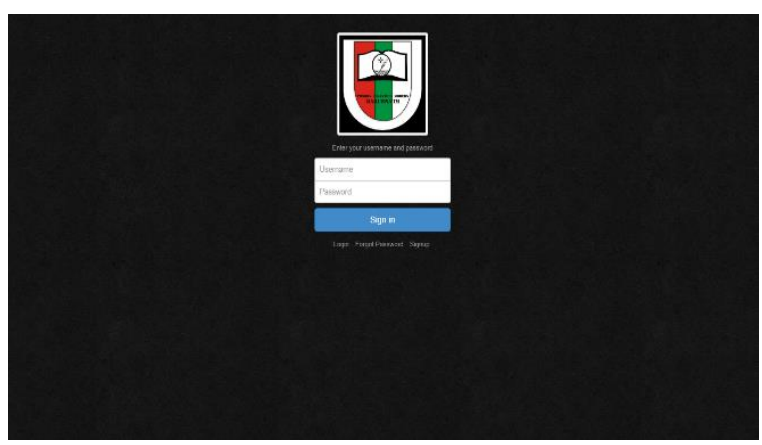

Gambar 10. Halaman Login Admin

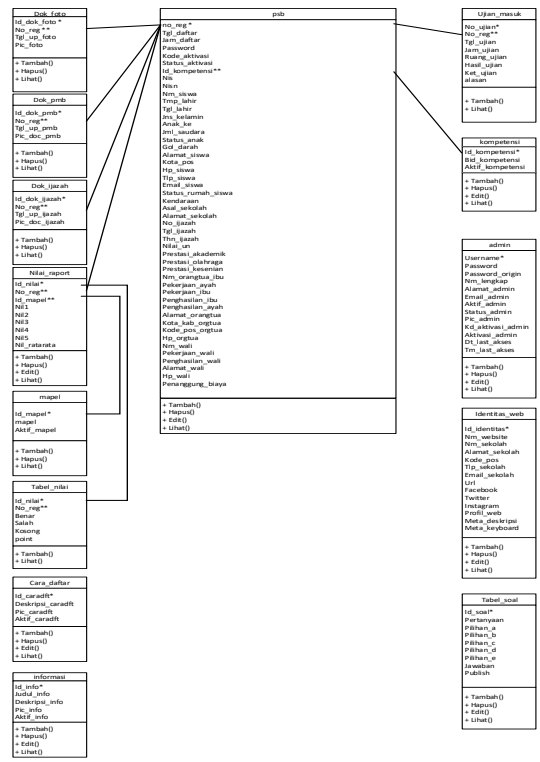

Gambar 9. Logical Record Structure (LRS)

b) Tampilan Halaman Login User

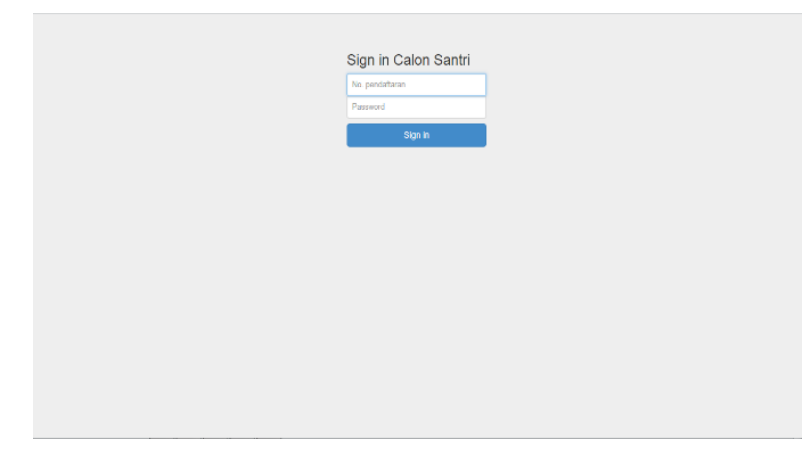

Gambar 11. Halaman Login User 
c) Tampilan Halaman Home

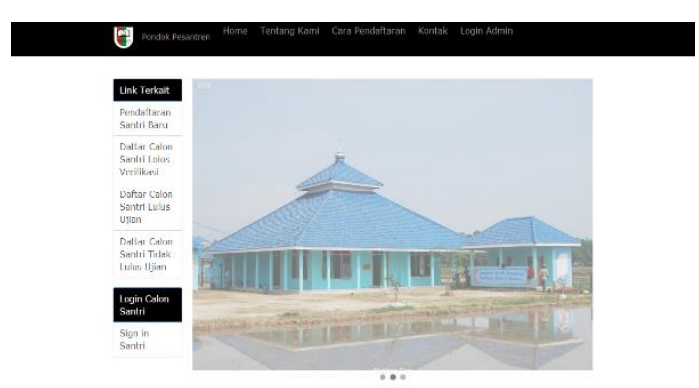

Gambar 12. Halaman Home

e) Tampilan Cara Pendaftaran

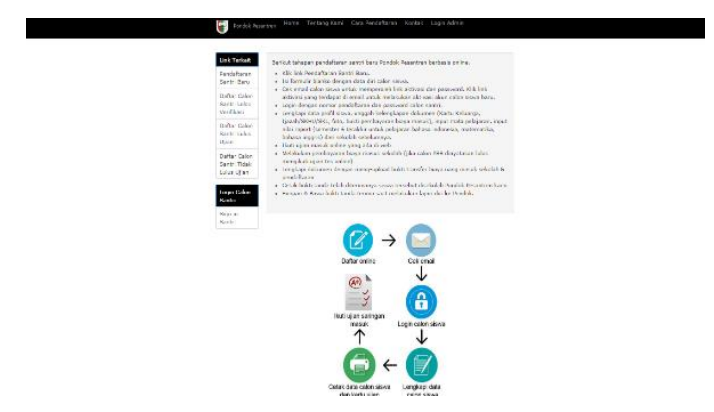

Gambar 14. Halaman cara pendaftaran

g) Tampilan Halaman Pendaftaran Santri

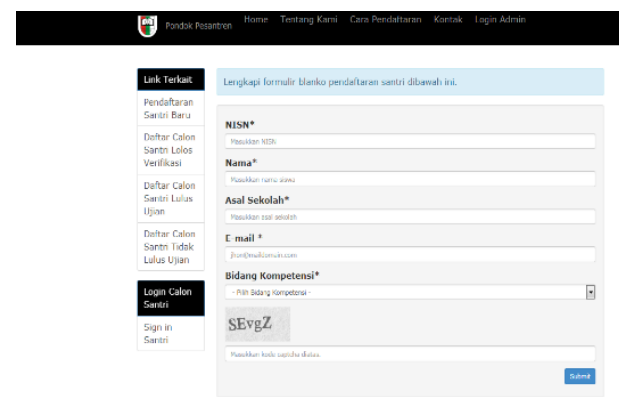

Gambar 16. Halaman Pendaftaran Santri

I) Tampilan Halaman Ujian Online

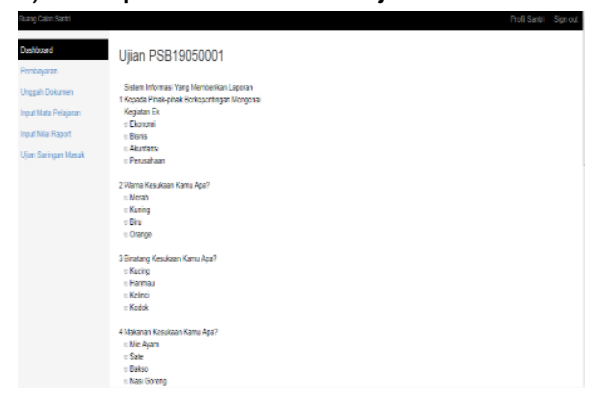

Gambar 18. Halaman Ujian online d) Tampilan Halaman About
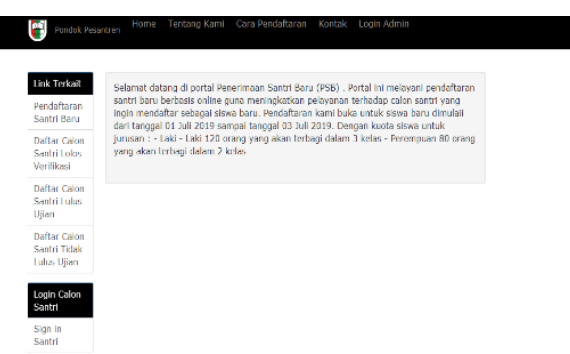

Gambar 13. Halaman About

f) Tampilan Halaman Kontak

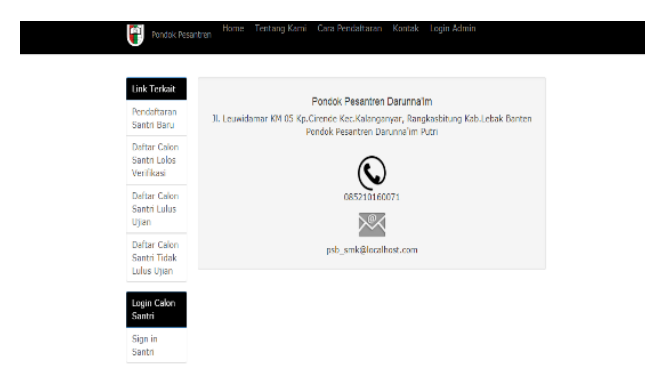

Gambar 15. Halaman Kontak

H) Tampilan Daftar Calon Santri Lolos

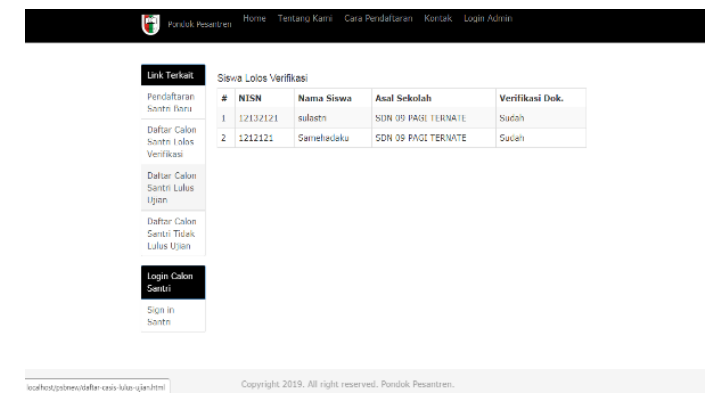

Gambar 17. Daftar Calon Santri Lolos

J) Tampilan Halaman Edit Soal Ujian

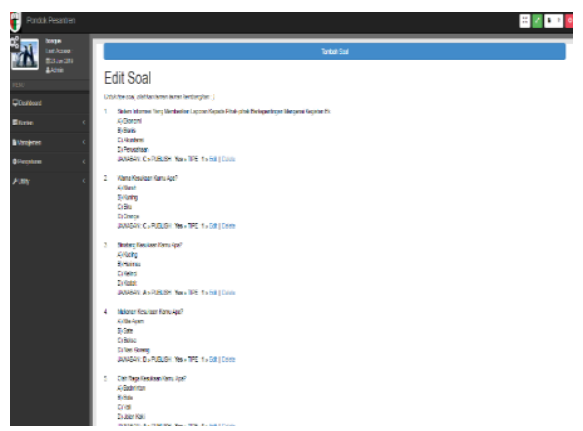

Gambar 19. Halaman Edit Soal Ujian 
m) Tampilan Dashboard Ruang Santri

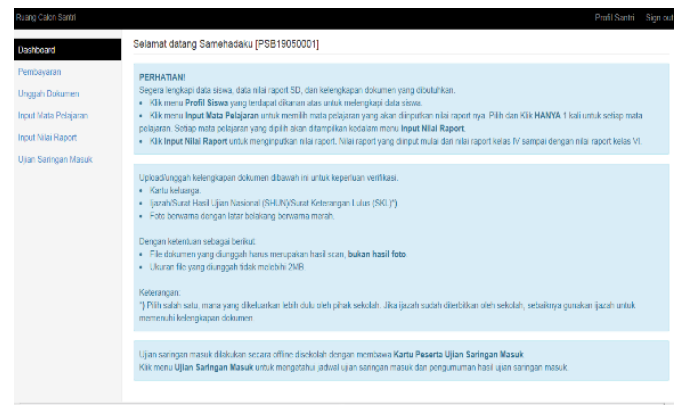

Gambar 22. Dashboard Ruang Santri n) Tampilan Halaman Dashboard Admin

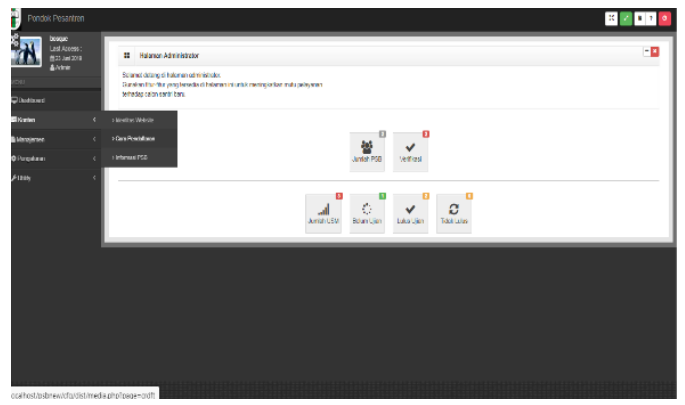

Gambar 23. Dashboard Admin

\section{B. Pengujian}

a) Blackbox Testing Login Admin

Tabel 1. BlackBox Testing Login Admin

\begin{tabular}{|c|c|c|c|c|c|}
\hline No & Skenario Pengujian & Text Case & $\begin{array}{c}\text { Hasil yang } \\
\text { diharapkan }\end{array}$ & $\begin{array}{c}\text { Hasil } \\
\text { Pengujian }\end{array}$ & Kesimpulan \\
\hline 1 & $\begin{array}{c}\text { Nama User dan Pass } \\
\text { tidak diisi }\end{array}$ & $\begin{array}{c}\text { User: Kosong } \\
\text { Pass: Kosong }\end{array}$ & $\begin{array}{c}\text { Sistem akan } \\
\text { Menolak }\end{array}$ & $\begin{array}{c}\text { Sesuai } \\
\text { Harapan }\end{array}$ & Valid \\
\hline 2 & Mengetik User Saja & $\begin{array}{c}\text { User : } 12151188 \\
\text { Pass: Kosong }\end{array}$ & $\begin{array}{c}\text { Sistem akan } \\
\text { Menolak }\end{array}$ & $\begin{array}{c}\text { Sesuai } \\
\text { Harapan }\end{array}$ & Valid \\
\hline 3 & Mengetikan pass saja & $\begin{array}{c}\text { User : Kssong } \\
\text { Pass : sadewa123 }\end{array}$ & $\begin{array}{c}\text { Sistem akan } \\
\text { Menolak }\end{array}$ & $\begin{array}{c}\text { Sesuai } \\
\text { Harapan }\end{array}$ & Valid \\
\hline 4 & $\begin{array}{c}\text { Mengetikan user benar } \\
\text { tapi pass salah }\end{array}$ & $\begin{array}{c}\text { User : } 12151188 \\
\text { Pass: qwerty }\end{array}$ & $\begin{array}{c}\text { Sistem akan } \\
\text { Menolak }\end{array}$ & $\begin{array}{c}\text { Sesuai } \\
\text { Harapan }\end{array}$ & Valid \\
\hline 5 & $\begin{array}{c}\text { Mengetikan user dan } \\
\text { pass yang benar }\end{array}$ & $\begin{array}{c}\text { User : } 12151188 \\
\text { Pass: sadewa123 }\end{array}$ & $\begin{array}{c}\text { Sistem akan } \\
\text { Menerima } \\
\text { akses login }\end{array}$ & $\begin{array}{c}\text { Sesuai } \\
\text { Harapan }\end{array}$ & Valid \\
\hline
\end{tabular}

b) Blackbox testing Login User

Tabel 2. BlackBox Testing Halaman Calon Santri

\begin{tabular}{|c|c|c|c|c|c|}
\hline No & $\begin{array}{c}\text { Skenario } \\
\text { Pengujian }\end{array}$ & Text Case & Hasil yang diharapkan & $\begin{array}{c}\text { Hasil } \\
\text { Pengujian }\end{array}$ & Kesimpulan \\
\hline 1 & $\begin{array}{c}\text { Mengisi Form } \\
\text { lalu submit }\end{array}$ & Mengisi Form & $\begin{array}{c}\text { System akan menampilkan } \\
\text { pesan berhasil }\end{array}$ & $\begin{array}{c}\text { Sesuai } \\
\text { Harapan }\end{array}$ & Valid \\
\hline 2 & $\begin{array}{c}\text { Mengaktivasi } \\
\text { Akun }\end{array}$ & $\begin{array}{c}\text { Klik Link yang } \\
\text { terdapat pada } \\
\text { email }\end{array}$ & $\begin{array}{c}\text { Sistem akan menampilkan } \\
\text { pesan bahwa akun } \\
\text { tervertifikasi }\end{array}$ & $\begin{array}{c}\text { Sesuai } \\
\text { Harapan }\end{array}$ & Valid \\
\hline 3 & $\begin{array}{c}\text { Login ke Ruang } \\
\text { Santri }\end{array}$ & $\begin{array}{c}\text { Copy-Paste ID } \\
\text { dan Password } \\
\text { pada email }\end{array}$ & $\begin{array}{c}\text { Sistem akan menerima } \\
\text { akses login }\end{array}$ & $\begin{array}{c}\text { Sesuai } \\
\text { Harapan }\end{array}$ & Valid \\
\hline 4 & Mengisi Biodata & $\begin{array}{c}\text { Mengisi semua } \\
\text { form pada } \\
\text { halaman profil }\end{array}$ & $\begin{array}{c}\text { Sistem akan } \\
\text { menampilakan bahwa data } \\
\text { sudah terisi }\end{array}$ & $\begin{array}{c}\text { Sesuai } \\
\text { Harapan }\end{array}$ & Valid \\
\hline 5 & Melakukan & $\begin{array}{c}\text { Mengisi semua } \\
\text { soal }\end{array}$ & $\begin{array}{c}\text { Sisem akan menghitung } \\
\text { benar dan salah }\end{array}$ & $\begin{array}{c}\text { Sesuai } \\
\text { Harapan }\end{array}$ & Valid \\
\hline
\end{tabular}




\section{E. KESIMPULAN}

1. Kesimpulan

Adapun kesimpulan yang dapat dihasilkan dari penelitian yang telah dilakukan yaitu sebagai berikut :

a. Web sistem informasi pendaftaran santri baru ini dapat dijalankan pada browser yang terdapat pada pc/laptop.

b. Web sistem informasi pendaftaran santri baru ini bertujuan sebagai media pendaftaran secara online pada pondok pesantren modern darunna'im.

c. Fitur dan tampilan yang terdapat pada halaman web santri ini berupa cara pendaftaran,upload dokumen,upload nilai raport dan lain sebagainya.

d. Fitur dan tampilan y'ang terdapat pada halaman admin yakni mempermudah administrasi serta proses penerimaan santri baru.

e. Terdapat pula fitur untuk menyeleksi para pendaftar yakni denan ujian saringan masuk secara online.

\section{Saran}

Untuk pengembangan lebih lanjut, saran-saran yang diberikan oleh user pada web pendaftaran santri baru ini, sebagai berikut :

a. Web ini bisa dikembangkan untuk device lainnya.

b. Pengembangan Desain lebih menarik untuk kedepannya.

c. Pada mode ujian saringan masuk dikembangakan dalam penyeleksian lebih terstruktur.

d. Penambahan fitur chat us untuk informasi lebih lanjut.

e. Maintenance secara bertahap untuk mengatasi bug dan perubahan data yang sering terjadi..

REFERENSI

Aprilyani, Firda, and Syarifuddin. 2016. "Sistem Informasi Penerimaan Peserta Didik Baru (Ppdb) Online Berbasis Web Dan Sms." (1): 47-52.

Kuryanti, Sandra J. 2016. "Rancang Bangun Sistem E-Learning Sebagai Sarana Pemberlajaran Sandra." Jurnal Khatulistiwa Informatika 4(1): 84-92.

Kusmiati, Herlinda. 2017. $10 \mathrm{llmu}$ Komputer "REKAYASA PERANGKAT LUNAK MEDIA INFORMASI."

Maisyaroh. 2014. "RANCANG BANGUN SISTEM INFORMASI SIMPAN PINJAM PADA KOPERASI." : 11-16.

Maulidya. 2018. "APLIKASI SISTEM INFORMASI PENDAFTARAN SISWA BARU PADA SMK BERBASIS WEB."

Mulyani, Astriana, and Dale Hasanudin. 2018. "APLIKASI WAREHOUSE CONTROLING BERBASIS ANDROID." 2(4): 46-54.

Nugraha, Fajar. 2014. "Analisa Dan Perancangan Sistem Informasi Perpustakaan.” 5(1): 27-32.

Sidik, Fajar, and Mari Rahmawati. 2018. "Perancangan Sistem Informasi Pendaftaran Siswa Baru Berbasis Web Pada SMK Bina Putra Jakarta." XX(1): 119-28. 